\title{
Gambaran Status Periodontal dan Kebutuhan Perawatan Anak Tunarungu Usia Sekolah di Sekolah Luar Biasa GMIM Damai Tomohon
}

\author{
Christy Mintjelungan ${ }^{1}$, Kustina Zuliari ${ }^{2}$, Elvira Yesika ${ }^{3}$ \\ ${ }^{1}$ Dosen Program Studi Kedokteran Gigi, Fakultas Kedokteran, Universitas Sam Ratulangi \\ ${ }^{2}$ Dinas Kesehatan Kota Manado \\ ${ }^{3}$ Mahasiswa Program Studi Kedokteran Gigi, Fakultas Kedokteran, Universitas Sam Ratulangi
}

\begin{abstract}
ABSTRAK
Anak tunarungu ialah anak yang memiliki hambatan dalam pendengaran dan biasanya memiliki hambatan dalam berbicara. Pada umumnya anak tunarungu memiliki keterbatasan dalam berkomunikasi sebagai akibat dari gangguan pendengaran yang dialaminya. Hal ini dapat menimbulkan hambatan di dalam penilaian maupun pemeliharaan kesehatan rongga mulut, yang meliputi kesehatan gigi dan jaringan penyangga gigi (jaringan periodontal). Tujuan dari penelitian ini ialah untuk mengetahui gambaran status periodontal dan kebutuhan perawatan anak tunarungu usia sekolah di Sekolah Luar Biasa (SLB) GMIM Damai Tomohon. Metode penelitian yang digunakan yaitu penelitian deskriptif dengan rancangan penelitian studi cross sectional, yaitu dengan memeriksa dan mencatat langsung hasil dari pemeriksaan status periodontal. Subjek penelitian dipilih dengan metode purposive sampling yaitu anak tunarungu usia sekolah di SLB GMIM Damai Tomohon sebanyak 32 anak. Penilaian status periodontal dan kebutuhan perawatan dilakukan berdasarkan indeks CPITN. Hasil penelitian menunjukkan bahwa status jaringan periodontal yang paling banyak ditemukan pada subjek penelitian ialah kalkulus, terdapat 29 orang $(90,6 \%)$ memiliki status periodontal kalkulus. Kebutuhan perawatan yang paling banyak dibutuhkan ialah kebutuhan perawatan Edukasi Instruksi Kesehatan Mulut dan Skeling (EIKM + SK).
\end{abstract}

Kata kunci : Status periodontal, anak tunarungu, kebutuhan perawatan

\begin{abstract}
Deaf children are children who have hearing impairment and also usually have disabilility in speaking. Generally, Deaf children have limitation in communication as a result of hearing loss. It can lead to lack of assessment and maintenance the oral health, including teeth and periodontal tissues health. The purpose of this study is to describe the periodontal status and the treatment needs in deaf children of school age at SLB GMIM Damai Tomohon. The study is a descriptive cross sectional study, that examined and recorded directly the result of the periodontal status. The subjects were selected by purposive sampling method that deaf children of school age at SLB GMIM Damai Tomohon as many as 32 children. Assessment of periodontal status and treatment needs are based on CPITN index. The results showed that the periodontal status are most frequently found on this study subjects is the calculus. There were 29 people (90.6\%) have calculus in their periodontal status. Treatment needs that needed the most is Education and Instructrion of Oral Health + Scaling (EIKM + SK).
\end{abstract}

Keyword : Periodontal status, deaf children, treatment needs

Korespondensi: Elvira Yesika, Program Studi Kedokteran Gigi, Fakultas Kedokteran Universitas Sam Ratulangi, Manado, Indonesia. E-mail: elviraysika@gmail.com

\section{PENDAHULUAN}

Anak penyandang cacat ialah setiap anak yang mempunyai kelainan fisik dan/atau mental yang dapat mengganggu atau merupakan rintangan dan hambatan baginya untuk melakukan kegiatan secara selayaknya yang terdiri dari penyandang cacat fisik, penyandang cacat mental, serta penyandang cacat fisik dan mental. Salah satu kelompok penyandang cacat yaitu anak 
tunarungu. Anak tunarungu ialah anak yang memiliki hambatan dalam pendengaran dan biasanya memiliki hambatan dalam berbicara sehingga mereka biasa disebut juga tunawicara. ${ }^{1}$ Menurut organisasi kesehatan dunia (WHO), lebih dari 5\% dari populasi dunia, sekitar 360 juta orang mengalami gangguan pendengaran (328 juta orang dewasa dan 32 juta anak-anak). ${ }^{2}$

Pada umumnya anak tunarungu memiliki keterbatasan dalam berkomunikasi sebagai akibat dari gangguan pendengaran yang dialaminya. Hal ini dapat menimbulkan hambatan di dalam penilaian maupun pemeliharaan kesehatan rongga mulut. ${ }^{3}$ Kesehatan rongga mulut, yang meliputi kesehatan gigi dan jaringan penyangga gigi (jaringan periodontal) merupakan hal penting dalam kesehatan dan kesejahteraan tubuh secara umum serta sangat memengaruhi kualitas kehidupan, termasuk didalamnya yaitu fungsi bicara, pengunyahan, dan rasa percaya diri. ${ }^{4}$

Menurut beberapa penelitian, status kesehatan rongga mulut, yang mencakup jaringan periodontal, pada anak-anak yang memiliki keterbatasan biasanya lebih buruk dibandingkan dengan anak-anak normal pada umumnya. ${ }^{5,6,7}$ Menurut penelitian yang dilakukan Nurisa pada anak tunarungu usia sekolah di Yogyakarta tahun 2011 menunjukkan bahwa status kesehatan jaringan periodontal yang buruk pada anak tunarungu disebabkan oleh kebersihan mulut yang kurang diperhatikan karena keterbatasan kemampuan dalam menjaga kebersihan gigi. $^{8}$

Berdasarkan survei awal, Sekolah Luar Biasa (SLB) Gereja Masehi Injili di Minahasa (GMIM) Damai Tomohon, merupakan satu-satunya SLB khusus tunarungu yang berada di provinsi Sulawesi Utara. Diketahui juga bahwa di SLB ini belum pernah dilakukan penelitian mengenai kesehatan rongga mulut maupun keadaan jaringan periodontal para siswa SLB GMIM Damai Tomohon.
Penelitian ini bertujuan untuk memperoleh gambaran status periodontal dan kebutuhan perawatan anak tunarungu usia sekolah di SLB GMIM Damai Tomohon.

\section{BAHAN DAN METODE}

Penelitian ini merupakan penelitian deskriptif dengan menggunakan rancangan penelitian studi cross-sectional. Jumlah sampel yang diteliti sebanyak 32 orang dengan teknik pengambilan sampel purposive sampling. Pengumpulan data diperoleh berdasarkan pemeriksaan dengan Community Periodontal Index of Treatment Needs (CPITN). Orang tua/wali dari subjek penelitian diminta untuk mengisi informed concent terlebih dahulu sebelum dilakukan pemeriksaan. Data yang diperoleh, diolah dan dianalisis menggunakan program Statistical Product and Service Solution (SPSS) dan penyajian data dalam bentuk tabel distribusi frekuensi.

\section{HASIL PENELITIAN}

Tabel 1. Distribusi subjek penelitian berdasarkan jenis kelamin

\begin{tabular}{lcc}
\hline $\begin{array}{c}\text { Jenis } \\
\text { Kelamin }\end{array}$ & $\begin{array}{c}\text { Jumlah } \\
(\mathrm{n})\end{array}$ & $\begin{array}{c}\text { Persentase } \\
(\%)\end{array}$ \\
\hline Laki-laki & 18 & 56,3 \\
Perempuan & 14 & 43,8 \\
\hline Total & 32 & 100 \\
\hline
\end{tabular}

Tabel 2. Distribusi subjek penelitian berdasarkan usia

\begin{tabular}{ccc}
\hline Usia & $\begin{array}{c}\text { Jumlah } \\
(\mathrm{n})\end{array}$ & $\begin{array}{c}\text { Persentase } \\
(\%)\end{array}$ \\
\hline $11-15$ tahun & 21 & 65,6 \\
$16-20$ tahun & 11 & 34,4 \\
\hline Total & 32 & 100 \\
\hline
\end{tabular}


Tabel 3. Distribusi status periodontal berdasarkan skor CPITN

\begin{tabular}{cccc}
\hline Skor CPITN & Status Periodontal & Jumlah $(\mathrm{n})$ & Persentase (\%) \\
\hline Skor 0 & Sehat & 1 & 3,1 \\
Skor 1 & Perdarahan pada gingiva & 1 & 3,1 \\
Skor 2 & Kalkulus & 29 & 90,6 \\
Skor 3 & Poket dangkal & 1 & 3,1 \\
Skor 4 & Poket dalam & 0 & 0 \\
\hline Total & & 32 & 100 \\
\hline
\end{tabular}

Tabel 4. Distribusi skor rata-rata CPITN pada setiap sektan $(\mathrm{n}=32)$

\begin{tabular}{cc}
\hline Sektan & Skor rata-rata CPITN \\
\hline Sektan 4 & 1,19 \\
Sektan 1 & 1,09 \\
Sektan 6 & 1,00 \\
Sektan 5 & 0,88 \\
Sektan 3 & 0,78 \\
Sektan 2 & 0,31 \\
\hline
\end{tabular}

Tabel 5. Distribusi kategori kebutuhan perawatan subjek penelitian

\begin{tabular}{ccc}
\hline Kategori Kebutuhan & Jumlah (n) & Persentase (\%) \\
Perawatan & 1 & 3,1 \\
EIKM & 1 & 3,1 \\
EIKM + SK & 30 & 93,8 \\
EIKM + PK & 0 & 0 \\
\hline Total & 32 & 100 \\
\hline
\end{tabular}

\section{PEMBAHASAN}

Subjek dalam penelitian ini berjumlah 32 orang dan karakteristiknya dibagi berdasarkan jenis kelamin dan usia. Tabel 1 menunjukkan bahwa karakteristik subjek penelitian berdasarkan jenis kelamin terdiri dari 18 orang $(56,3 \%)$ berjenis kelamin lakilaki dan 14 orang $(43,8 \%)$ berjenis kelamin perempuan. Jumlah subjek penelitian yang berjenis kelamin laki-laki lebih banyak daripada perempuan. Tabel 2 menunjukkan bahwa karakteristik subjek penelitian berdasarkan usia dibagi dalam dua kelompok, yaitu kelompok usia $11-15$ tahun dan kelompok usia 16 - 20 tahun. Pembagian ini didasarkan pada penilaian skor CPITN. Untuk usia 15 tahun kebawah dapat memperoleh penilaian skor CPITN 0, 1 , dan 2, sedangkan untuk 16 tahun keatas dapat memperoleh penilaian skor CPITN 0, $1,2,3$, dan $4 .^{4}$

Hasil penelitian pada tabel 3 menunjukkan bahwa dari 32 orang yang menjadi subjek penelitian, terdapat 29 orang yang memperoleh skor 2 yang menggambarkan status periodontal adanya kalkulus baik supragingiva maupun subgingingiva. Hasil penelitian ini menunjukkan bahwa status jaringan periodontal yang paling banyak ditemukan pada subjek penelitian ialah kalkulus. Hal serupa juga ditemukan pada penelitian yang dilakukan oleh Nurisa (2011) di SLB Karnnamanohara Yogyakarta yang menunjukkan status jaringan periodontal tertinggi pada anak tunarungu usia sekolah ialah kalkulus. ${ }^{8}$ Pada penelitian Ameer N, et al (2012) di distrik Nalgonda, India juga mendapatkan status periodontal tertinggi pada remaja tunarungu ialah kalkulus. ${ }^{3}$ Kalkulus ialah plak terkalsifikasi yang terbentuk dan melekat erat pada permukaan gigi, dan objek solid lainnya di dalam mulut, misalnya restorasi dan gigi-geligi tiruan., ${ }^{4,9}$

Pada penelitian ini kalkulus yang ditemukan pada subjek penelitian merupakan kalkulus supragingiva. Kalkulus supragingiva ialah kalkulus yang melekat 
pada permukaan mahkota gigi mulai dari puncak gingival margin dan dapat dilihat. Kalkulus ini berwarna putih kekuningkuningan, konsistensinya keras dan mudah dilepaskan dari permukaan gigi menggunakan skeler. ${ }^{4} \quad$ Kalkulus supragingiva yang ditemukan pada anak tunarungu usia sekolah dapat disebabkan oleh perilaku yang kurang tepat dalam menjaga kebersihan gigi dan mulut. Hal ini dapat terjadi akibat keterbatasan yang mereka miliki, yakni gangguan pendengaran yang dapat menimbulkan hambatan dalam berkomunikasi sehingga penyampaian informasi mengenai kesehatan gigi dan mulut, termasuk mengenai cara-cara menjaga kebersihan gigi dan mulut tidak dapat diterima dengan baik. Perilaku menjaga kebersihan gigi dan mulut yang tidak tepat dapat mengakibatkan penumpukan plak yang kemudian dapat terkalsifikasi menjadi kalkulus supragingiva oleh peran serta saliva. Mineral pada kalkulus supragingiva berasal dari saliva. Oleh karena itu, kalkulus supragingiva juga disebut salivary calculus. ${ }^{4,10}$

Hasil penelitian pada tabel 4 menunjukkan distribusi skor rata-rata CPITN pada setiap sektan. Skor rata-rata CPITN pada setiap sektan dapat memberikan gambaran mengenai besarnya masalah periodontal yang ditemukan pada setiap sektan. Semakin tinggi skor rata-rata CPITN pada suatu sektan, semakin banyak permasalahan yang ditemukan pada sektan tersebut.Skor rata-rata CPITN paling tinggi terdapat pada sektan 4 yang merupakan regio posterior kanan mandibula. Jumlah skor rata-rata CPITN tertinggi di sektan 4 ialah 1,19. Hal ini menunjukkan bahwa regio tersebut memiliki kondisi periodontal yang paling bermasalah. Hal serupa juga ditemukan pada penelitian yang dilakukan oleh Nurisa (2011) di SLB Karnnamanohara Yogyakarta yang juga mendapatkan skor rata-rata CPITN tertinggi pada regio posterior kanan mandibula. ${ }^{8}$ Masalah yang paling banyak ditemukan pada daerah ini ialah adanya kalkulus. Kalkulus dapat terjadi akibat gigi geligi yang tidak dibersihkan dengan baik. ${ }^{9}$ Skor rata-rata CPITN terendah terdapat pada sektan 2 yang merupakan regio anterior maksila. Jumlah skor rata-rata
CPITN terendah di sektan 2 ialah 0,31. Hal ini menunjukkan bahwa regio tersebut memiliki kondisi periodontal yang paling jarang bermasalah. Regio anterior maksila merupakan regio yang mudah dibersihkan karena letaknya yang mudah dijangkau dalam penyikatan gigi sehingga regio ini kebersihannya lebih terjaga. Berdasarkan data yang terdapat pada tabel 4 juga dapat dilihat bahwa skor rata-rata CPITN pada sektan 5 yang merupakan regio anterior mandibula lebih tinggi daripada skor ratarata CPITN pada sektan 2 yang merupakan regio anterior maksila. Skor rata-rata CPITN pada sektan 5 ialah 0,88 sedangkan skor rata-rata CPITN pada sektan 2 ialah 0,31. Hal ini menunjukkan bahwa regio anterior mandibula memiliki kondisi periodontal yang lebih banyak bermasalah dibandingkan dengan regio anterior maksila. Hal ini serupa dengan teori yang mengatakan bahwa daerah lingual gigi anterior mandibula pada umumnya merupakan lokasi yang banyak ditemukan kalkulus supragingiva dikarenakan pada daerah tersebut terpapar saliva langsung dari glandula saliva submandibularis dan sublingualis. ${ }^{4,11}$

Hasil penelitian pada tabel 5 menunjukkan bahwa dari 32 orang subjek penelitian, terdapat 30 orang $(93,8 \%)$ masuk dalam kategori kebutuhan perawatan Edukasi Instruksi Kesehatan Mulut dan Skeling (EIKM+SK). Hal ini menunjukkan bahwa kebutuhan perawatan yang paling banyak dibutuhkan oleh subjek penelitian ialah kebutuhan perawatan EIKM+SK. Kebutuhan perawatan EIKM + SK merupakan kategori bagi subjek penelitian yang mengalami kondisi periodontal kalkulus dan poket dangkal. ${ }^{4}$

\section{SIMPULAN}

Berdasarkan hasil penelitian, maka dapat diambil kesimpulan bahwa status periodontal berdasarkan skor CPITN yang paling banyak ditemukan pada subjek penelitian ialah skor 2 yang menggambarkan status periodontal kalkulus. Selain itu, skor rata-rata CPITN tertinggi pada subjek penelitian terdapat pada sektan 4 (regio posterior kanan mandibula) dan skor ratarata CPITN terendah pada sektan 2 (regio anterior maksila), dan kebutuhan perawatan 
yang paling banyak dibutuhkan ialah kebutuhan perawatan Edukasi Instruksi Kesehatan Mulut dan Skeling (EIKM+SK).

\section{SARAN}

Disarankan kepada Dinas Kesehatan khususnya di daerah Tomohon untuk memberikan sosialisasi berupa penyuluhan dan pelatihan kepada para tenaga pengajar di SLB GMIM Damai Tomohon mengenai cara memelihara kesehatan rongga mulut yang meliputi kesehatan gigi dan jaringan periodontal. Bagi pihak SLB GMIM Damai Tomohon juga disarankan untuk mengadakan program edukasi kesehatan rongga mulut bagi para siswa serta penyuluhan kepada orangtua/wali mengenai upaya pemeliharaan kesehatan rongga mulut anak, serta bagi para siswa SLB GMIM Damai Tomohon dan orang tua/walinya disarankan untuk berkonsultasi dengan dokter gigi untuk melakukan perawatan skeling sebagai upaya penanganan kalkulus.

\section{DAFTAR PUSTAKA}

1. Direktorat Jenderal Bina Kesehatan Masyarakat, Direktorat Bina Kesehatan Anak, Kementerian Kesehatan Republik Indonesia. Pedoman pelayanan kesehatan anak di sekolah luar biasa (SLB) bagi petugas kesehatan. [serial online] 2010 [cited 2013 Apr 10]. Available from : URL: http://www.depkes.go.id/downloads/Pe doman\%20Pelayanan\%20Kesehatan\%2 0Anak.pdf

2. Deafness and hearing loss. World Health Organization [online]. [cited 2013 April 12]; Available from : URL: http://www.who.int/mediacentre/factsh eets/fs300/en/

3. Ameer N, Palaparthi R, Neerudu M, Palakuru SK, Singam HR, Durvasula S. Oral hygiene and periodontal status of teenagers with special needs in the district of Nalgonda, India. Journal of Indian Society of Peridontology [serial online] Jul-Sep 2012 [cited 2013 Apr 10]; 16(3): 421-5. Available from: URL:

http://www.jisponline.com/temp/JIndia nSocPeriodontol1634211593342_042533.pdf
4. Putri MH, Herijulianti E, Nurjanah N. Ilmu pencegahan penyakit jaringan keras dan jaringan pendukung gigi. Jakarta : Buku Kedokteran EGC. 2010. h. 1,85,87,207,209.

5. Purohit BM, Singh A. Oral health status of 12-year-old children with disabilities and controls in Southern India. WHO South-East Asia Journal of Public Health [serial online] 2012 [cited 2013 Apr 12]; 1(3):330-8. Available from : URL:

http://www.searo.who.int/publications/j ournals/seajph/whoseajphv1i3p330.pdf

6. Hashemi Z, Hajizamani A, Bozorgmehr E, Omrani F. Oral health status of a sample of disabled population in Iran. JOHOE [serial online] 2012 [cited 2013 Apr 12]; 1(1):23-8. Available from : URL:

http://johoe.kmu.ac.ir/index.php/johoe/ article/download/8/4

7. Nahar SG, Hossain MA, Howlader MBU, Ahmed A. Oral health status of disabled children. Bangladesh Med Res Counc Bull [serial online] 2010 [cited 2013 Mei 2]; 36:61-3. Available from : URL:

http://www.banglajol.info/index.php/B MRCB/article/view/6989/5306

8. Nurisa. Status kesehatan jaringan periodontal anak tunarungu usia sekolah sebagai penunjang total care pada anak penyandang ketunaan [serial online] 2011 [cited 2013 Mei 2]; Available from : URL: http://digilib.fk.umy.ac.id/files/disk1/13 lyoptumyfkpp-gdl-nurisa-624-1naskahp-i.pdf

9. Manson JD, Eley BM. Buku ajar periodonti. $2^{\text {nd }}$ ed. Jakarta: Hipokrates. 1993. h. 26-7

10. Reddy S. Essentials of clinical periodontology and periodontics, $3^{\text {th }}$ ed. New Delhi : Jaypee Brothers Medical Publishers Ltd. 2006. p. 70.

11. Hinrichs JE. The role of dental calculus and other local predisposing factors. In: Newman, Takei, Klokkevold, Carranza. Carranza's Clinical Periodontology, $11^{\text {th }}$ ed. St. Louise,Missouri: Saunders Elsevier, Inc. 2006. p. 217. 